\title{
Exploring the Feasibility of Implementing Flipped Classroom Concept in Engineering Education.
}

\author{
Pulok Ranjan Mohanta ${ }^{1}$, Amit Kumar Singh ${ }^{2}$ \\ ${ }^{1}$ Department of Mechanical Engineering, Laxmi Institute of Technology, Sarigam, Gujarat \\ ${ }^{2}$ Department of Mathematics, Laxmi Institute of Technology, Sarigam, Gujarat \\ 1'pulokmohanta@gmail.com, ${ }^{2}$ singh.amitkk@gmail.com
}

\begin{abstract}
With the rapidly changing global economy accompanied by faster up gradation of technology and frequent introduction of newer technologies into day to day life, it becomes necessary for almost everything to change in accordance to the present day scenario. This implies to the education field as well. And if we focus on professional course like engineering, the objectives of the courses can better be met by adapting to the present day scenario. In engineering education it becomes essential for the method of instruction to build the appropriate level of understanding of the concepts and phenomena that are taught during the lecture hour. To develop problem solving skill enough practice is also required. In earlier days the concept of teaching was like "sage on stage", wherein the lessons were delivered by teacher in the class room and students practice problems in their home. Though this method was the only option due to the unavailability of adequate technology, now new concept called Flipped Classroom is emerging which converts the classical concept of teaching to "guide by side". It tries to utilize the new common habit of the students to use technological devices worldwide. It can be
\end{abstract}

\section{Pulok Ranjan Mohanta}

Department of Mechanical Engineering,

Laxmi Institute of Technology, Sarigam, Gujarat

pulokmohanta@gmail.com observed that most of them spend much of their time accessing the internet for various purposes such as chatting on social media or accessing online materials (Fisher, 2009) Technology provides and shares the information instantaneously among the users, in college for example, the students and teacher can easily access the online contents of teaching and learning from their laptops, computers or Smartphone everywhere and anytime (Fu, 2013) This scenario gave an opportunity to emerge the concept of Flipped Classroom. This pedagogical method enables the better delivery of the lessons and helps the students develop better understanding of the concepts being taught. In this paper the author attempts to provide the concept and theory of implementing flipped learning approach for students and lecturers in engineering education.

Keywords: Flipped Classroom, engineering education, ICT in education, active learning, collaborative learning

\section{Introduction to Flipped Classroom concept:}

The flipped classroom is a pedagogical model in which the typical lecture and homework elements of a course are reversed. Short video lectures are viewed by students at home before the class session, while in 
class time is devoted to exercises, projects, or discussions.

In this method, teachers record their lessons using simple video capture software, and share them amongst the students through internet or other means and assign the recordings for online viewing prior to class and the classroom teaching hour is to be used for collaborative activities. This shift allows teachers to transition out of their role of "sage on the stage" and become facilitators, or "guides on the side" thereby allowing students to move away from being passive listeners and becoming active participants in the learning process. Numerous free online learning materials like videos lessons, documents, case studies etc. are available in the internet which can be accessed by every student everywhere and at their convenience. Research indicates that compared to those in traditional lecture-based classes, students in active learning environments show improved retention and better conceptual understanding of learned material (Sezer, 2010). These results are attributed to the contrasting roles of passive and active learners in the educational process. While passive learners exist solely as receivers, active learners are full participants in the process, allowing them to add to their retentive capabilities through continued self-reinforcement (Petress, 2008). By allowing students to use knowledge in class with feedback from peers and the teacher, flipped classrooms help students to correct their misconceptions and organize new knowledge effectively. Thus Flipped classroom allows the teacher to act as a facilitator in the classroom and to guide the students in learning lessons (Baker, 2011).

Based on this concept there are 4 key elements of the flipped classroom identified by Vanderbilt University's Center for Teaching (Brame, 2013):

1. To provide an opportunity for students to gain first exposure to content prior to class.

2. To provide an incentive for students to prepare for class.

3. To provide in-class activities that focus on higherlevel cognitive activities.

4. To provide a mechanism to assess student understanding.

So flipped classroom can be defined as an educational technique that consists of two parts: interactive group learning activities inside the classroom, and direct computer-based individual instruction outside the classroom. A graphic representation of this definition is shown in Figure 1.

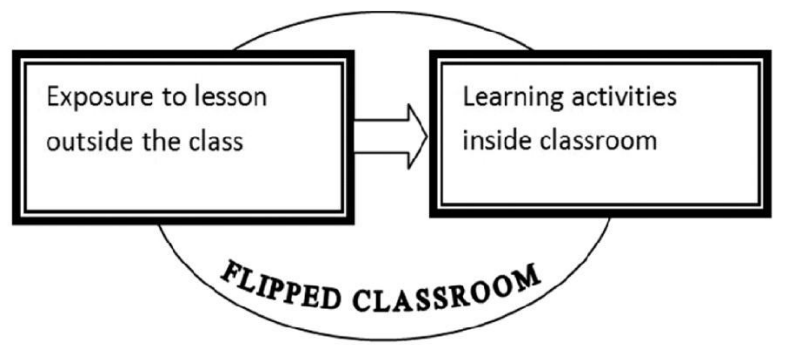

Figure 1. Flipped Classroom

\section{The overview of experiences of Flipped Classroom.}

The flipped classroom model intends to bring students' learning experience to a whole new level. With the flipped classroom, students can find the class time to be more meaningful and personal where they can experience more control over their learning (Baker, 2011). In the survey conducted by Lage and colleagues (2000), it was reported that students preferred the flipped classroom in comparison to the traditional lecture. The teachers were able to approach and work with individual students during the class time without sacrificing any course coverage (Lage et al., 2000). The flipped classroom model allows teachers to spend more time with struggling students and allows more freedom to the advanced learners to work independently. Bergmann (2011) reported that with the lesson carried outside the classroom, he now had time to have one-on-one interactions with the students. According to Fritzky (2013), normally about fifteen to twenty minutes would be spent to explain new concepts to students, and along the way there will be interruptions by students asking questions if they do not understand. However with the learning taken outside the classroom and posted online as video, students had the freedom to stop and replay the video if there are parts that they do not understand. The extra time Fritzky had in class was fully utilized for the students to apply concepts and solve real-world problems. Based on Fritzky's study, the success of flipping the classroom was evidenced by the improvement of students' results and was reported as record-breaking.

Some experienced that in the flipped classroom model, not all lessons of a subject have to be "flipped". It is most beneficial to certain topics that contain large amount of content or concept that needed to be understood before the practical work and the 
application can be done. But According to Afstrom (2013), once a classroom is flipped it will never go back to the traditional state. The concept of inverting the 1classroom means transitioning the classroom from being teacher-centred to students-centred and most likely will not shift back the other way. This is supported by the findings of Wrights (2012). When Wrights (2012) flipped her classroom, she developed the students' thinking skills by prompting them to reflect on their learning and teaching them how to evaluate and work with their peers. She realized that after one year of flipping her classroom her students began to do more research on their own to the extent that they did not need her videos anymore to learn. Eventually the flipped lessons disappeared completely and even she had stopped lecturing in class. Wrights experienced what Baker (2011) had reported; the students were in control of their learning. The classroom became a place where the students built their own knowledge and shared their findings.

Despite the benefits of having lessons outside the classroom, Hertz (2012) pointed out the challenges of implementing it. To access the learning material outside the classroom normally requires computer and Internet access. This may not be a problem for urban areas but has always been an issue in the rural and semi urban areas. Though the number of smartphone users is increasing across all regions, the penetration of high speed internet is still poor for remote locations. The availability of computers in such places is often limited. To add to that, the Internet connections in institutions are known to be weak. This factor discouraged students to access the online lesson. However, the lack of technology and accessibility was not an issue for Wrights (2012). She used whatever devices her students had; a couple of IPads, a few computers and students' cell phones. Those students without any devices shared with the others who had and made it work.

In a traditional classroom, little effort is required from the students in teaching hours. With this model of flipped classroom, students are to take responsibility for their own learning. If they have not viewed the lesson outside the classroom, it could be difficult for them to follow the lesson within the classroom. This technique of teaching might not be as effective as it should be. From the study of Johnson and Renner (2012), there were students in a class that practiced flipped teaching who did not participate in the lesson outside the classroom. The class then technically split into two, which made it difficult for the teacher to group and assist the students in their learning. It is important for the students to understand that in order to succeed, the students have to take responsibility of their learning, not only in the classroom but also outside the classroom. Additionally, Johnson and Renner (2012) stated that if having homework is not a routine or the common culture for the class, it would be an obstacle to having an effective flipped teaching.

\section{The Structure of Flipped Classrooms}

The structure of the course is what determines if it is a flipped classroom. It can be consisting of the following situations:

Before class: Students watch video lectures or perform other activities to expose them to content. The lectures can be broken into smaller conceptual chunks that can be helpful for students to manage content.

During class: Students participate in active learning activities to deepen their understanding of the content. Brief quizzes can be introduced to check for understanding and help students and teachers to identify misunderstandings and ensure that the student get the desired concept.

After class: Students complete homework assignments independently to practice mastery of learned concepts. Since part of the students' homework is learning the content for the next class, students are assigned with less traditional homework than in a normal class.

Intermittently: Students complete assessments and provide feedback about course and learning activities. Student feedbacks can be taken before major assessments to address issues.

\section{Learning models for Flipped Classrooms:}

Flipped classrooms can vary greatly depending on the attributes of the class, student needs, and the level of involvement required by the teacher. Some possible learning models are outlined here.

\section{Teacher-led model}

In an teacher-led flipped classroom, the teacher is typically involved in every aspect of the course and has ample opportunities to engage with students. 
Outside of class, students engage with the more passive elements of the course; inside class, students participate in active learning activities coordinated by the teacher. Such activities might include group discussions, role-playing games, case studies, group problem solving, team projects, etc.

\section{Student-Led Model}

In a student led flipped class, the teacher's involvement in the day to day running of the course is relatively low. The teacher acts more as an organizer or guide in the learning process, providing resources and support necessary to allow learners to direct their own learning (e.g., answering student questions online or holding office hours, providing feedback on student work, motivating students).

\section{Suitability in Engineering Education:}

Today every university is developing the curriculum of engineering disciplines to cope with the present and future needs of the industries. The objectives being to equip the graduates the necessary knowledge and skill to make them competent to solve the real life problems. In order to meet these objectives students are given exposure to a huge amount of knowledge and information during their course work. The syllabi are also adopting interdisciplinary topics to meet the required standard.

When observed from student point of view it becomes a tough job to grab the basic fundamental subject knowledge along with knowing the recent developments in the field. It also becomes difficult for the teachers to provide them with every information with in the short teaching duration as prescribed by the syllabi. This problem can be efficiently addressed by the implementation of the FLIPPED CLASSROOM concept.

Another justification can be obtained from the view of the understanding the concepts. Most of the theories can easily be explained by the teacher in the conventional teaching style. But this may not be the case while explaining application part of the concepts, the phenomena, the working of equipment etc. These things can easily be understood when by referring to the audio visual resources. To develop the required understanding, it depends greatly on IQ of the students which definitely differs from student to student. The conventional teaching thus sometimes leads to frustration or inferiority feeling among the slow learners. If the students are given a chance to explore the content of the lesson in advance at their comfort, it will definitely be helpful for them, as they will be having the liberty to access at their ease. They can access the learning material at their ease and pace and as many times as required. This may also give them the option to select the depth of knowledge they want to explore for different topics of the curriculum.

\section{Steps to flip the class:}

While flipping the class the teachers need to follow the following steps:

\section{A. Is the Flipped Model Appropriate for My Class?}

Before implementing a classroom flip, teachers should carefully assess whether the model is appropriate for their curriculum and students. Critical considerations include whether the students will be receptive to a change in instructional ideology, whether the subject material will translate well to the new format, and whether the technology is accessible for all teachers and students.( Hanover Research (2013).

\section{B. Content considerations}

The teacher must ensure that the resources being suggested to refer should be adequately dealing with the requirements of the curriculum and sufficient to develop the required level of understanding. Digital content and online and in $\square$ class activities should be complementing each other, and be part of a single design process. The teacher may develop his own materials or may use the online available contents.

\section{Scheduling of the topics.}

It forms a necessary component of teachinglearning process. The teacher must make a proper sequence of the topics so that the syllabus is easily comprehended by the learners. The duration of the individual topic should also be prepared keeping in view of the difficulty level for the target learners.

\section{Sharing the materials.}

The resource material if customized by the teacher must be shared with learners at proper time by proper means. Any online materials if referred, the teacher must share the proper link so that the students can easily access them at appropriate time. Now a days 
many online platforms are available for conducting online teaching programs. They also enable teachers to organize virtual classes effectively.

\section{E. Monitoring the class}

If the teachers are taking the help online platform for flipping their class, they can easily monitor their class. The real time analysis of the class is also possible. The teacher must ensure that the students spend the minimum required time referring the learning materials. Teacher may assign numerous exercises or quizzes for each topic to ensure students get the desired outcome of the course. They should adhere to the schedule of the quizzes to maintain the uniformity in learning. Teacher should also provide scope to the students for interaction with the teacher if any assistance is required.

\section{F. Discussion in the class.}

The next step is to discuss the topic in the class where the learning of the students will be shared with each other. It has to be supervised by the teacher so that any misconception developed is corrected. This will provide the opportunity to the teacher to give special emphasis to any of the concepts if it is required. For this step different techniques like group discussion, quiz, problem solving etc. can be implemented. Here the teacher must declare the conclusion or outcome of the discussion session so that students get the clear idea of what they have learnt comparing to the intended course objective.

\section{G. Evaluation of the performance.}

At the end of the course a test must be conducted to measure the performance of the students for that course before they face the final examination. This will indicate the effectiveness of flipping the class.

\section{H. Documentation}

Any special observation and experience should be documented so that it to be used to bring any possible improvement.

\section{Pitfalls of the flipped classroom approach}

A. Students new to the method may be initially resistant because it requires that they do work at home rather than be first exposed to the subject matter in school. Consequently, they may come unprepared to class to participate in the active learning phase of the course. Faculty can solve this problem by giving a short quiz either online or in class or by requiring homework that references information that can only be obtained from the outside reading or videos.

B. The learning material must be carefully tailored for the students in order to prepare them for the in-class activities. For most teachers (and students), videos are the method of choice for delivering the out-of-class portion of the instruction. However, in the survey, teachers found difficulty in finding good quality videos. They used videos produced by different online sources. They then post these to YouTube, iTunes U, or on course management systems like Blackboard or Moodle. The quality of the teacher-created videos is often marginal, and creating them requires a significant amount of time.

C. Students may prefer to remain absent in class. While flipping a class can increase attendance, some students feel they do not need to come to class because they can access the lectures online. Teachers therefore must ensure to explain the benefits of attending class, organize class quizzes to boost attendance, or Make class attendance part of the grading system.

D. Flipped classrooms are susceptible to becoming an over load and lengthy, because teachers may not adapt homework assignments to accommodate the extra homework that students perform during the video lectures. Use of student feedback can ensure that the course isn't too time intensive.

\section{Conclusion}

Implementing Flipped Classroom will definitely have its challenges largely dependent on the use and management of technology. Despite these challenges, the Flipped Classroom has the potential to be proved as a novel and effective teaching approach for engineering education. The format of the Flipped Classroom will provide more opportunities for students to engage in critical thinking, independent learning and more effectively collaborative learning. Additionally, the teacher will get more flexibility to cover a wider range and depth of material related to the lesson. The teacher can thus stimulate different creative ideas by giving opportunity to students to explore a large quantity of information at their ease. So adopting to the concept of flipped class room will take advantage of the increasing addiction of students to their electronic gadgets to enhance the 
understanding of the subject matter. The teachers are advised to try in their classes and observe the response of the students. By taking care of possible pitfalls and responding appropriately to the observations every teacher can effectively implement this concept to a greater success level.

\section{References}

1 Fisher D. (2009), The use of instructional time in the typical high school classroom, The Educational Forum. 73(2), 168-176.

$2 \mathrm{Fu} \mathrm{J.} \mathrm{S.(2013),} \mathrm{ICT} \mathrm{in} \mathrm{Education} \mathrm{:} \mathrm{A} \mathrm{Critical}$ Literature Review and Its Implications, International Journal of Education \& Development using Information \& Communication Technology, 9(1), 112-125.

3 Brame, C. J.(2013).Flipping the classroom. $\mathrm{http}: / / \mathrm{cft}$.vanderbilt.edu/teaching-guides/ teachingactivities/flipping-the-classroom/

4 Petress, K. (2008). What Is Meant by "Active Learning?". Education, 128(4), 566-569.

5 Sezer, R. (2010). Pulling out All the Stops. Education, 130(3), 416-423.

6 Baker, J. W. (2011). The origins of "The Classroom Flip". Unpublished manuscript. Department of $\mathrm{M}$ e d i a $\&$ Applied Communications, Cedarville University, Cedarville, $\mathrm{OH}$

7 Lage, M., Platt, G., \& Treglia, M. (2000). Inverting the classroom: A gateway to creating an inclusive learning environment. Journal of Economic Education, 31(1), 30-43.

8 Strayer, J. (2007). The effects of the classroom flip on the learning environment: A comparison of learning activity in a traditional classroom and a flip classroom that used an intelligent tutoring system (Unpublished doctoral dissertation). The Ohio State University, Columbus, Ohio.

9 Bergmann, J. (2011). History of the flipped class: How the flipped class was born. Retrieved from http://blendedclassroom.blogspot.com/2011/05/h istory-of-flipped-class.html

10 Fritzky, J. (2013). Before and after the flipped class. Retrieved from http://flippedlearning.com/?p=1136

11 Arfstrom,K.(2013).How to reach struggling students: Once you flip, you'll never go back. Retrieved from http://flipped - learning.com/?p= 1190 \# more-1190

12 Wright, S. (2012). The flip: End of a love affair. Retrieved from http://plpnetwork.com/2012/10/ 08/flip-love-affair/

13 Hertz, M. B. (2012). The flipped classroom: Pro and con. Retrieved from http://www.edutopia.org /blog/flipped-classroom- pro-and-con-mary-bethhertz

14 Johnson, L. W., \& Renner, J. D. (2012). Effect of the flipped classroom model on a secondary computer applications course: Student and teacher perceptions, questions and student achievement (Unpublished doctoral dissertation). University of Louisville, Louisville, Kentucky.

15 Hanover Research (2013). Best Practices for the Flipped Classroom.Retrieved from http://www.hanoverresearch.com/2013/10/best $\%$ practicesforthe \%flipped\%classroom/ 